\title{
Isolation and Characterization of Bacteria from Sewage and Pond Water, Malda, India
}

\section{Moumita Sarkar, Shiladitya Chakraborty, Debabrata Kundu, Souradip Ghosh, Ankita Khan, Debankar Karmakar, Sarafat Ali and Shyamapada Mandal*}

Laboratory of Microbiology and Experimental Medicine, Department of Zoology, University of Gour Banga, Malda, India

*Corresponding Author: Shyamapada Mandal, Professor, Laboratory of Microbiology and Experimental Medicine, Department of Zoology, University of Gour Banga, Malda, India. E-mail: samtropmed@gmail.com

Received: September 23, 2019; Published: October 14, 2019

DOI: $10.31080 /$ ASMI.2019.02.0394

\begin{abstract}
Reports are available in scientific literature on the multiple antibiotic resistances of potential pathogenic bacteria from different aquatic environments, globally. This study explores the diversity of bacteria in sewage wastewater and pond water, and assesses the antibiotic resistance of the isolated bacteria. Two water samples: sewage wastewater $(\mathrm{n}=1)$ and pond water $(\mathrm{n}=1)$ were collected from around the University (Malda, India), and were processed in isolation of bacteria, which were characterized for identification following phenotypic techniques. The antibiotic resistance profile was determined based on the disc diffusion method, and the multiple antibiotic resistance (MAR) indices were calculated for the isolated bacteria. A total of 14 bacteria was isolated from the water samples studied, among which 3 were gram-negative, and 11 were gram-positive, either coccus $(n=1)$ or rods $(n=10)$. Among the isolated bacteria $(n=14), 6$ isolates displayed multiple antibiotic resistance to $\geq 3$ antibiotics, the MAR indices for which ranged 0.6 - 0.8, while in 7 isolates that expressed resistance to two antibiotics had MAR indices of 0.4; a single strain had resistance to methicillin. Thus, this is imperative for the regular vigilance of such wastewater bacteria in order to combat the bacterial multiple antibiotic resistances.
\end{abstract}

Keywords: Sewage Wastewater; Pond Water; Potentially Pathogenic Bacteria; Phenotypic Characterization; Multiple Antibiotic Resistance; MAR Index

\section{Introduction}

The bacterial antibiotic resistance has been reported as one of the most serious threats to the human as well as environmental health of this time, though antibiotics had tackled in the past many critical situations in clinical practices [1,2]. The occurrence of resistance to multiple antibiotics among bacteria, having the capacity to cause many health threats to humans, is not uncommon, in our times, in the environment, including aquatic bodies [3-5]. Sidhu., et al. [6] demonstrated the presence of coliform bacteria, such as Escherichia coli, on bacteriological analysis of drinking water from different schools in Northern India. There has been a report on the isolation of potential pathogenic bacteria (both gram-negative and gram-positive), from fish pond water in the Niger Delta region, Nigeria [7]. Mukhopadhyay., et al. [8] isolated multiple antibiotic resistant bacteria, from household water samples, including, Pseudomonas aeruginosa, coliforms and Enterococcus spp., in Karnataka, India. Mulamattathil., et al. [9] reported about the isolation and identification of bacteria from sewage water samples (Mafikeng, South Africa), and determined the antibiotic resistance profiles of the isolated bacteria. As has been reported by Ajayi., et al. [10], the pond water was contaminated with gram-positive (Streptococcus sp., Staphylococcus aureus, and Bacillus sp.) and gram-negative (Escherichia coli, Pseudomonas sp., Klebsiella sp., Enterobacter sp., Proteus sp., Cytrobacter sp., and Shigella sp.) bacteria. Different 
gram-negative bacteria showing resistance to multiple antibiotics have been reported as the biological contaminants of natural water sources [3]. Several authors from different parts of the world demonstrated the fact of bacterial MAR indices as the useful tool for determining the level of antibiotic pollution in the given ecological niches [11,12]. In our earlier report, a high range of MAR indices among gram-negative and gram-positive bacteria, from environmental sources, have been demonstrated [13]. The current study has, therefore, been undertaken to ascertain the presence of potential pathogenic bacteria in sewage and pond wastewater, and to determine the antibiotic resistance profiles of the isolated bacteria.

\section{Materials and Methods}

The wastewater samples ( $\mathrm{n}=2$; sample I from sewage system and sample II from lotus pond) were collected (during the month April, 2019) from around the University of Gour Banga, Malda (West Bengal, India), and were processed microbiologically for the isolation of bacteria, as described before [13]. The morphologically distinct bacteria cultures (colonies), as procured by streak-dilution method utilizing Mueller-Hinton agar (Hi-Media, India), from the wastewater samples were maintained at the ambient temperature in cystine tryptone agar (Hi-Media, India) stabs, for further studies.

The isolated bacteria were characterized following phenotypic techniques (colony morphology study, gram-staining and biochemical tests, including sugar fermentation) for identification, according to Halt [14] and Forbes., et al. [15], as explained elsewhere [13].

The isolated bacteria were subjected to the susceptibility testing to five antibiotics (Hi-Media, India): ampicillin (AMP: $10 \mu \mathrm{g} /$ disc), chloramphenicol (C: $30 \mu \mathrm{g} /$ disc), gentamicin (GEN: $10 \mu \mathrm{g}$ / disc), methicillin (MET; $5 \mu \mathrm{g} /$ disc) and piperacillin (PI: $100 \mu \mathrm{g} /$ disc), following disc diffusion [16]. The results, in terms of ZDI (zone diameter of the inhibition) values of the test antibiotics, were interpreted following the guidelines of the Clinical and Laboratory Standards Institute [17].

The MAR indices for the isolated sewage wastewater bacteria were calculated following the formula published earlier [13] and the results were interpreted following the criteria of Krumperman [11]. The antibiotic resistance phenotypes were determined, for the isolates, according to Adefisoye and Okoh [12]; the isolates with resistance to $\geq 3$ test antibiotics expressed multiple antibiotic resistance phenotypes.

\section{Results and Discussion}

In the increasingly and injudiciously used ages of antibiotics (not only in clinical practices, in veterinary medicine and in agri- cultural practices too), there has been an acceleration in the emergence and dissemination of multiple antibiotic resistant (MAR) bacteria, restricting the efficacies of the currently available antibiotics in curing human diseases (of bacterial infections), worldwide $[1,18]$. Obviously, the antibiotic resistances are not limited in clinical settings, rather reported in agricultural as well as various environmental settings, and foods $[19,20]$. Previously, we have reported the isolation of potentially pathogenic bacteria from the riverine as well as municipal sewage wastewater receiving polluted effluents in Malda, India [21,22].

A total of 14 wastewater bacteria isolated (10 isolates from the sample I: S1W1, S1W2, S1W3, S1W4, S1W5, S1W6, S1W7, S1W8, S1W9 and S1W10, and 4 isolates from sample II: S2W1, S2W2, S2W3 and S2W4), displayed varied morphological features of their colonies developed on nutrient agar plates (Figure 1). Among the isolated bacteria (Figure 2), 3 were gram-negative rods (S1W6, S1W10 and S2W4), and the other 11 isolates were either gram-positive rods ( $\mathrm{n}=10$; S1W1, S1W2, S1W3, S1W4, S1W5, S1W8, S1W9, S2W1, S2W2 and S2W3) or gram-positive cocci ( $n=1$; S1W7). The biochemical and sugar fermentation test results of the isolated bacteria have been represented in table 1 and table 2 . The bacteria as identified, following phenotypic characterization, are depicted in table 3 .

\begin{tabular}{|l|c|c|c|c|c|c|c|c|}
\hline $\begin{array}{l}\text { Strain } \\
\text { code }\end{array}$ & \multicolumn{7}{|c|}{ Biochemical tests } \\
\hline & TSI & $\begin{array}{c}\text { Ci- } \\
\text { trate }\end{array}$ & $\begin{array}{c}\text { In- } \\
\text { dole }\end{array}$ & $\begin{array}{c}\text { Cata- } \\
\text { lase }\end{array}$ & $\begin{array}{c}\text { Oxi- } \\
\text { dase }\end{array}$ & MR & VP & $\begin{array}{c}\text { DN- } \\
\text { ase }\end{array}$ \\
\hline S1W1 & Y/Y & - & - & + & - & - & + & + \\
\hline S1W2 & Y/Y & + & - & + & + & - & + & - \\
\hline S1W3 & Y/Y & + & - & + & + & - & + & - \\
\hline S1W4 & $\mathrm{P} / \mathrm{Y}$ & - & - & + & + & + & + & + \\
\hline S1W5 & $\mathrm{Y} / \mathrm{Y}$ & + & - & + & - & + & - & - \\
\hline S1W6 & $\mathrm{P} / \mathrm{Y}$ & - & - & + & + & - & - & + \\
\hline S1W7 & $\mathrm{Y} / \mathrm{Y}$ & - & - & + & + & - & - & + \\
\hline S1W8 & $\mathrm{Y} / \mathrm{Y}$ & - & - & + & + & + & - & - \\
\hline S1W9 & $\mathrm{P} / \mathrm{Y}$ & + & - & + & + & - & + & + \\
\hline S1W10 & $\mathrm{P} / \mathrm{P}$ & + & - & + & + & - & - & - \\
\hline S2W1 & $\mathrm{Y} / \mathrm{Y}$ & + & - & + & + & - & + & - \\
\hline S2W2 & $\mathrm{Y} / \mathrm{Y}$ & - & - & + & + & - & - & - \\
\hline S2W3 & $\mathrm{P} / \mathrm{Y}$ & - & - & + & + & + & - & + \\
\hline S2W4 & $\mathrm{P} / \mathrm{P}$ & + & - & + & + & - & - & - \\
\hline
\end{tabular}

Table 1: Biochemical test results for bacteria isolated from wastewater samples

MR: Methyl red; VP: Voges-Proskaur; P: Pink; Y: Yellow; -: Negative; +: Positive; TSI: Triple sugar iron. 


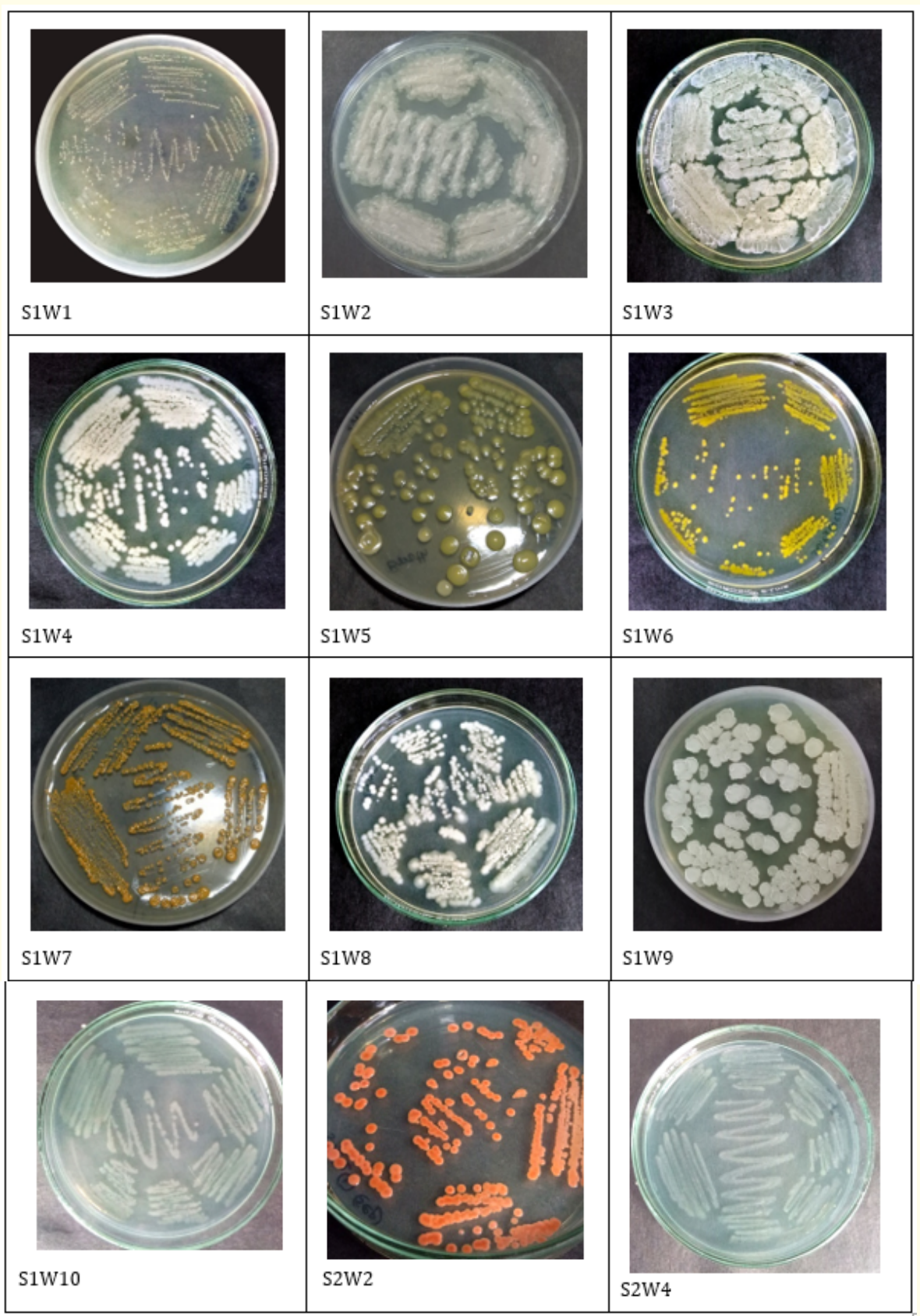

Figure 1: Colony characteristics of bacteria isolated from wastewater samples. 


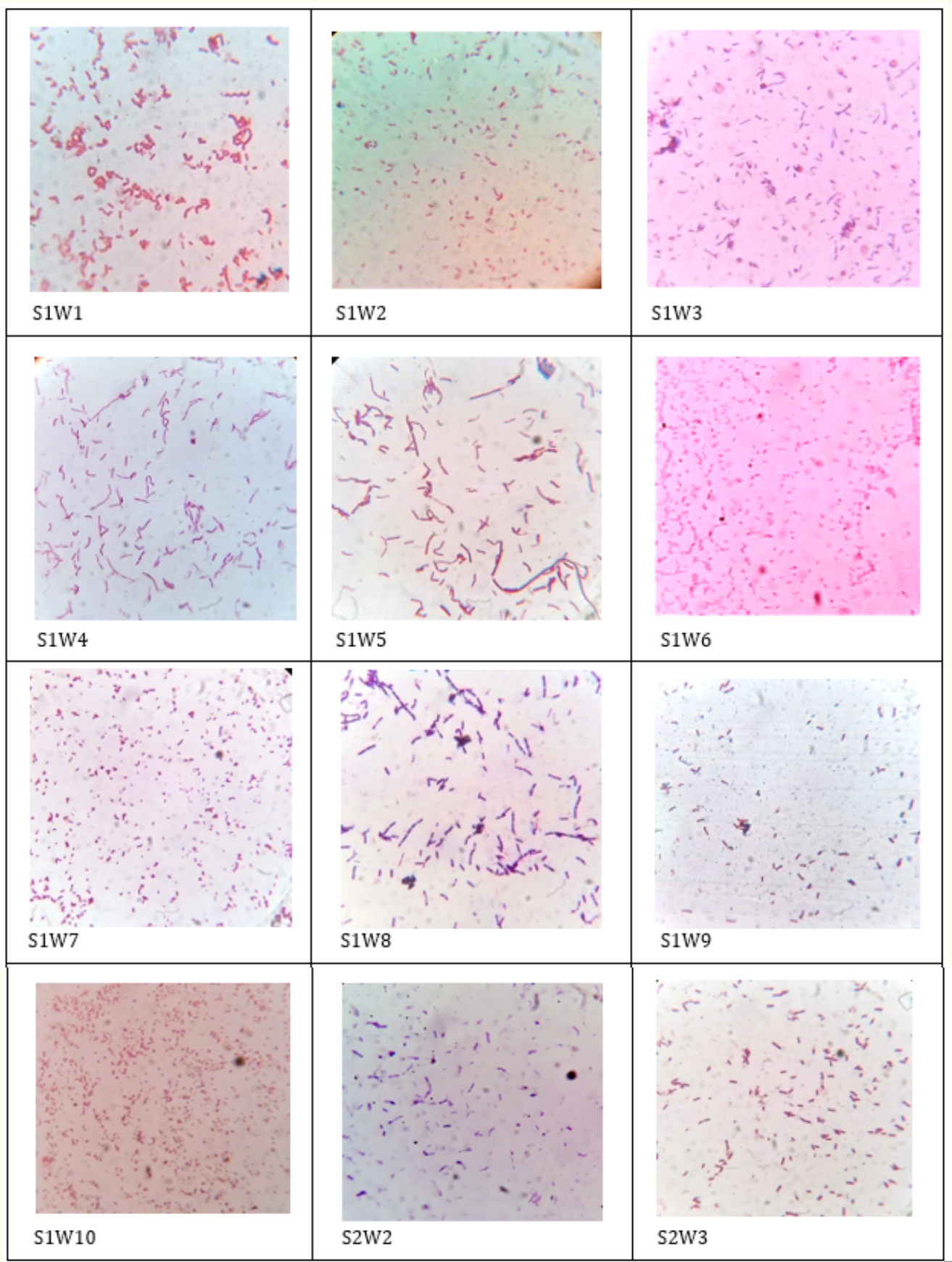

Figure 2: Gram staining property of bacteria isolated from wastewater samples. 


\begin{tabular}{|l|c|c|c|c|c|}
\hline $\begin{array}{l}\text { Strain } \\
\text { code }\end{array}$ & \multicolumn{5}{|c|}{ Sugars } \\
\hline & Sorbitol & Sucrose & Lactose & Maltose & Mannitol \\
\hline S1W1 & + & + & + & + & + \\
\hline S1W2 & + & + & W & - & + \\
\hline S1W3 & - & W & - & - & - \\
\hline S1W4 & W & + & + & + & + \\
\hline S1W5 & + & + & - & - & W \\
\hline S1W6 & - & - & - & - & - \\
\hline S1W7 & + & + & + & + & + \\
\hline S1W8 & + & + & W & + & + \\
\hline S1W9 & - & W & - & - & - \\
\hline S1W10 & - & - & - & - & - \\
\hline S2W1 & W & + & + & + & + \\
\hline S2W2 & - & - & - & - & - \\
\hline S2W3 & + & + & W & + & W \\
\hline S2W4 & - & - & - & - & - \\
\hline
\end{tabular}

Table 2: Sugar fermentation test results for bacteria isolated from wastewater samples

W: Weakly positive; -: Negative; +: Positive.

\begin{tabular}{|l|c|}
\hline Strain code & Bacterial identity \\
\hline S1W1 & Corynebacterium xerosis \\
\hline S1W2 & Bacillus cereus \\
\hline S1W3 & Bacillus subtilis \\
\hline S1W4 & Bacillus cereus \\
\hline S1W5 & Bacillus megaterium \\
\hline S1W6 & Chryseobacterium indologenes \\
\hline S1W7 & Macrococcus luteus \\
\hline S1W8 & Bacillus circulans cereus \\
\hline S1W9 & Pseudomonas aeruginosa \\
\hline S1W10 & Bacillus cereus \\
\hline S2W1 & Bacillus indicus \\
\hline S2W2 & Bacillus circulans \\
\hline S2W3 & Pseudomonas aeruginosa \\
\hline S2W4 &
\end{tabular}

Table 3: Identity of bacteria isolated from wastewater samples.

It has been reported, the occurrence of bacterial contamination of natural resources of water with different bacteria (from rural areas of East Sikkim, India), such as Pseudomonas aeruginosa, Klebsiella pneumoniae, Escherichia coli, Proteus sp., Acinetobacter sp., Citrobacter sp., and Enterobactor sp., showing resistance to AMP, trimethoprim-sulfamethoxazole, cefixime, tetracycline, ceftazi-

dime, amikacin and GEN [3]. The antibiotic susceptibility test results, in terms of ZDIs, for the bacteria isolated are shown in figure 3. The antibiotic resistance phenotypes and the MAR indices of the isolated bacteria are represented in table 4. Apenteng., et al. [23] demonstrated the isolation of gram-negative bacteria, from the fish pond, that included Pseudomonas aeruginosa, Escherichia coli and Salmonella typhi showing resistance phenotypes: 'tetracyclineerythromycin', 'cefuroxime-tetracycline-erythromycin' and 'cefuroxime-tetracycline-erythromycin-ciprofloxacin', respectively.

The bacterial isolates, in the current study, showed resistance to one or more antibiotic tested; the lowest resistance to a single antibiotic (MET; MAR index: 0.2) was recorded for S2W2 strain, while the highest resistance to four antibiotics (resistance pattern: AMP-GEN-MET-PI; MAR index: 0.8) was displayed by S2W1 strain. Among 14 isolated bacteria, 6 displayed MAR phenotypes with resistance to 3 or more antibiotics, for which MAR indices ranged 0.6 - 0.8, while 7 isolates having resistance to two antibiotics had MAR indices of 0.4 (Table 4); the intermediate susceptibility was recorded for S2W1 strain to chloramphenicol, and for S1W9 and S2W4 strains to piperacillin. Poonia., et al. [3] expressed the concern of high antibiotic load in the natural water resources demonstrating the MAR indices of $>0.2$, among most of the bacterial isolates. As per the criteria reported earlier $[11,24,25]$, the instant study, wherein the MAR indices for the bacterial isolates ranged $0.2-0.8$, suggested their (isolated bacteria) association with niches having high levels of antibiotic contamination as well as the 'human fecalsource of origin' for most of the isolates.

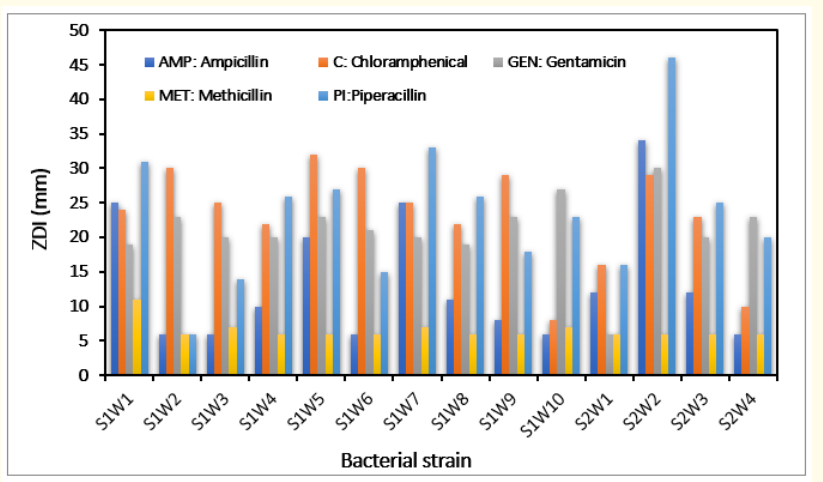

Figure 3: Antibiogram of isolated bacteria $(n=14)$. S1W1: Corynebacterium xerosis; S1W2: Bacillus cereus; S1W3: Bacillus subtilis; S1W4: Bacillus cereus; S1W5: Bacillus megaterium; S1W6: Chryseobacterium indologenes; S1W7: Micrococcus luteus; S1W8: Bacillus circulans; S1W9: Bacillus cereus; S1W10: Pseudomonas aeruginosa; S2W1: Bacillus cereus; S2W2: Bacillus indicus; S2W3: Bacillus circulans; S2W4: Pseudomonas aeruginosa. 


\begin{tabular}{|c|c|c|c|c|c|c|}
\hline \multirow[t]{2}{*}{ Isolated Bacteria } & \multicolumn{5}{|c|}{$\begin{array}{l}\text { Antibiotic resistance } \\
\text { profile }\end{array}$} & \multirow{2}{*}{$\begin{array}{l}\text { MAR } \\
\text { index }\end{array}$} \\
\hline & AMP & $\mathrm{C}$ & GEN & MET & PI & \\
\hline C. xerosis S1W1 & $\mathrm{R}$ & $\mathrm{S}$ & $\mathrm{S}$ & $\mathrm{R}$ & $\mathrm{S}$ & 0.4 \\
\hline B. cereus $\mathrm{S} 1 \mathrm{~W} 2$ & $\mathrm{R}$ & $\mathrm{S}$ & S & $\mathrm{R}$ & $\mathrm{R}$ & 0.6 \\
\hline B. subtilis S1W3 & $\mathrm{R}$ & $\mathrm{S}$ & $S$ & $\mathrm{R}$ & $\mathrm{R}$ & 0.6 \\
\hline B. cereus $\mathrm{S} 1 \mathrm{~W} 4$ & $\mathrm{R}$ & $\mathrm{S}$ & $\mathrm{S}$ & $\mathrm{R}$ & $\mathrm{S}$ & 0.4 \\
\hline B. megaterium S1W5 & $\mathrm{R}$ & $\mathrm{S}$ & $\mathrm{S}$ & $\mathrm{R}$ & $\mathrm{S}$ & 0.4 \\
\hline C. indologenes S1W6 & $\mathrm{R}$ & $\mathrm{S}$ & $\mathrm{S}$ & $\mathrm{R}$ & $\mathrm{R}$ & 0.6 \\
\hline M. luteus S1W7 & $\mathrm{R}$ & $\mathrm{S}$ & $\mathrm{S}$ & $\mathrm{R}$ & $\mathrm{S}$ & 0.4 \\
\hline B. circulans S1W8 & $\mathrm{R}$ & $\mathrm{S}$ & $\mathrm{S}$ & $\mathrm{R}$ & $\mathrm{S}$ & 0.4 \\
\hline B. cereus $\mathrm{S} 1 \mathrm{~W} 9$ & $\mathrm{R}$ & $\mathrm{S}$ & $\mathrm{S}$ & $\mathrm{R}$ & I & 0.4 \\
\hline P. aeruginosa S1W10 & $\mathrm{R}$ & $\mathrm{R}$ & $\mathrm{S}$ & $\mathrm{R}$ & $\mathrm{S}$ & 0.6 \\
\hline Bacillus cereus S2W1 & $\mathrm{R}$ & $\mathrm{I}$ & $\mathrm{R}$ & $\mathrm{R}$ & $\mathrm{R}$ & 0.8 \\
\hline B. indicus S2W2 & $\mathrm{S}$ & $\mathrm{S}$ & $\mathrm{S}$ & $\mathrm{R}$ & $\mathrm{S}$ & 0.2 \\
\hline B. circulans S2W3 & $\mathrm{R}$ & $\mathrm{S}$ & S & $\mathrm{R}$ & $\mathrm{S}$ & 0.4 \\
\hline P. aeruginosa S2W4 & $\mathrm{R}$ & $\mathrm{R}$ & $\mathrm{S}$ & $\mathrm{R}$ & I & 0.6 \\
\hline
\end{tabular}

\section{Bibliography}

1. Taneja N., et al. "Antimicrobial resistance in the environment: the Indian scenario". Indian Journal of Medical Research 149 (2019): 119-128.

2. Van Boeckel TP., et al. "Global antibiotic consumption 2000 to 2010: an analysis of national pharmaceutical sales data". The Lancet Infectious Diseases 14 (2014): 742-750.

3. Poonia., et al. "Antibiotic susceptibility profile of bacteria isolated from natural sources of water from rural areas of East Sikkim". Indian Journal of Community Medicine 39.3 (2014): 156-160.

4. Zhang XX., et al. "Antibiotic resistance genes in water environment". Applied Microbiology and Biotechnology 82 (2009): 397-414.

5. Baquero F., et al. "Antibiotics and antibiotic resistance in water environments". Current Opinion in Biotechnology 19 (2008): 260-265.

Table 4: Antibiotic resistance profiles and MAR indices for the isolated wastewater bacteria $(\mathrm{n}=14)$

AMP: ampicillin; C: chloramphenicol; GEN: gentamicin; MET: methicillin; PI: piperacillin.

\section{Conclusions}

The sewage wastewater, as demonstrated in the current study, supported the growth of gram-positive rods as well as cocci, and gram-negative rods too; wherein the diversity of gram-positive bacteria was greater, as compared to the gram-negative bacteria. The bacteria isolated are potential to cause human infections and possessed varied antibiotic resistances and MAR indices. Therefore, there is an urgent and imperative need to the regular vigilance of such environmental bacteria of clinical relevance, and to prepare effective Indian guidelines for judicious use of antibiotics in order to tackle the bacterial multiple antibiotic resistances.

\section{Author contribution}

Moumita Sarkar, Shiladitya Chakraborty, Debabrata Kundu, Souradip Ghosh, Ankita Khan, Debankar Karmakar and Md. Sarafat Ali, all performed experimental works and are recognized as joint first authors; Shyamapada Mandal designed the study, wrote and discussed the entire paper.

\section{Conflicts of Interest}

6. Sidhu S., et al. "Bacteriological analysis of the drinking water from different schools in Northern India: a concern in developing countries". International Journal of Medical Resarch and Review 4.4 (2016): 630-634.

7. Njoku., et al. "An investigation of the microbiological and physico-chemical profile of some fishpond water within the Niger Delta region of Nigeria". African Journal of Food Service 9.3 (2015): 155-162.

8. Mukhopadhyay C., et al. "Microbial quality of well water from rural and urban households in Karnataka, India: a cross-sectional study". Journal of Infection and Public Health 5 (2012): $257-262$.

9. Mulamattathil., et al. "Isolation of environmental bacteria from surface and drinking water in Mafikeng, South Africa, and characterization using their antibiotic resistance profiles". Journal of Pathogens (2014): 1-11.

10. Ajayi AO., et al. "Bacteriological study of pond water for aquaculture purposes". Journal of Food, Agriculture and Environment 12.2 (2014): 1260-1265.

11. Krumperman PH. "Multiple antibiotic resistance indexing of Escherichia coli to identify high-risk sources of fecal contamination of foods". Applied and Environmental Microbiology 46.1 (1983): 165-170.

There was no conflict of interest. 
12. Adefisoye MA., et al. "Ecological and public health implications of the discharge of multidrug-resistant bacteria and physicochemical contaminants from treated wastewater effluents in the Eastern Cape, South Africa. Water 9 (2017): 562.

13. Nandi S., et al. "Bacteriological profiling of commercially available eye cosmetics and their antibiotic susceptibility pattern". Translational Biomedicine 7.3 (2016): 1-8.

14. Holt JG. "Bergey's Manual of Systematic Bacteriology". Williams and Wilkins, Baltimore (1984).

15. Forbes BA., et al. "Bailey and Scott's diagnostic of microbiology”. 12th Edition, Mosby (Elsevier), USA (2007).

16. Bauer AW., et al. "Antibiotic susceptibility testing by a standard single diffusion method". American Journal of Clinical Pathology 45.4 (1966): 494-496.

17. Clinical and Laboratory Standards Institute (CLSI): Performance standards for antimicrobial susceptibility testing, 21st informational supplement M100S21. CLSI, Wayne, Pa (2011).

18. Li J., et al. "Colistin: the re-emerging antibiotic for multidrugresistant Gram-negative bacterial infections". The Lancet Infectious Diseases 6 (2006): 589-601.

19. Friedman M. "Antibiotic-resistant bacteria: prevalence in food and inactivation by food-compatible compounds and plant extracts". Journal of Agricultural and Food Chemistry (2015): 3805-3822.

20. Le TH., et al. "Occurrences and characterization of antibioticresistant bacteria and genetic determinants of hospital wastewater in a tropical country". Antimicrobial Agents and Chemotherapy 60 (2016): $7449-7456$.

21. Das S., et al. "Detection of mercury and cadmium resistance among multiple antibiotic resistant enteric bacteria from municipal sewage water in Malda, India". International Research Journal of Pharmacy 9.9 (2018): 171-176.

22. Das SN., et al. "Plasmid mediated antibiotic and heavy metal co-resistance in bacterial isolates from Mahananda river water (Malda, India). Transl Med (Sunnyvale) 6.4 (2016): 185.

23. Apenteng., et al. "Antibiotic sensitivity patterns of microbial isolates from fishponds: a study in the greater Accra region of Ghana". African Journal of Pharmacy and Pharmacology 11.28 (2017): 314-320.
24. Tambekar DH., et al. "MAR indexing to discriminate the source of faecal contamination in drinking water". Nature Environment and Pollution Technology 4 (2005): 525-528.

25. Kaneene BJ., et al. "Considerations when using discrimination function analysis of antimicrobial resistance profiles to identify sources of faecal contamination of surface water in Michigan". Applied and Environmental Microbiology 73 (2007): 2878-2890.

\section{Volume 2 Issue 11 November 2019}

(c) All rights are reserved by Shyamapada Mandal., et al. 